\title{
The demographic and economic transition in Central and Eastern Europe - Management implications*
}

\author{
Manfred Perlitz, Lasse Schulze, Christina B. Wilke**
}

Although the population in Central and Eastern European Countries (CEEC) is still younger, on average, than in Western Europe, the CEEC also have to cope with challenges caused by the demographic shift towards an ageing, shrinking population. Some countries are ageing even faster than Western Europe. Apart from ageing, the CEEC also have to face problems caused by the economic transition. Based on neo-institutional organisation theory this paper looks at the management implications of these developments and points out strategies for Human Resources Management and Marketing in how to cope with upcoming challenges.

Obwohl die Bevölkerung im Durchschnitt jünger als in Westeuropa ist, haben auch die Mittel- und Osteuropäischen Länder (MOEL) die Herausforderungen der demographischen Entwicklung durch eine alternde und schrumpfende Bevölkerung zu bewältigen. Manche Länder altern sogar noch schneller als Westeuropa. Neben der Alterung haben die MOEL auch Probleme des ökonomischen Übergangs zu verkraften. Dieser Artikel betrachtet-basierend auf dem neo-institutionalistischem Ansatz der Organisationstheorie - die Implikationen dieser Entwicklungen für das Management und zeigt Strategien für das Personalmanagement und Marketing auf, um diese bevorstehenden Herausforderungen zu bewältigen.

Keywords: Demography, Neo-Institutional Organisation Theory, Human Resources Management, Marketing, Pension Reform

* Manuscript received: 17.12.08, accepted: 22.04 .10 (1 revision)

** Manfred Perlitz, Prof., former Chair, Department of International Management, University of Mannheim, Germany. Main research areas: International management, intercultural management, innovation management and world scenarios.

Lasse Schulze, Dr., Project Manager, Bilfinger Berger of Industrial Services, Germany. Main research areas: International management, intercultural management and international corporate governance.

Christina B. Wilke, Dr. Managing Director of MEA, the Mannheim Research Insititute for the Economics of Aging, University of Mannheim. Main research interests: Implications of population aging on the subtainability of social security system and simulation models. Corresponding address: Wilke@mea.uni-mannheim.de. 


\section{Introduction}

The demographic shift towards ageing, shrinking populations and its implications are widely discussed in Western European countries like Germany. Although the population in Central and Eastern Europe (CEE) is still younger, on average, than in Western Europe, the Central and Eastern European Countries (CEEC) also have to cope with these problems. As a result of very low birth rates and increasing remaining life expectancies, some countries are ageing even more rapidly than Western Europe. Apart from ageing, the CEEC also have to cope with problems caused by the economic transition like unemployment and negative net migration, which has put additional pressure on the economy as a whole. As a consequence, labour force and consumption patterns will change and firms will need to adapt to these changes of their institutional context.

By applying neo-institutional organisation theory this paper (a) summarizes the demographic and economic trends and their main policy implications and (b) looks at the management implications of these developments in two distinct areas: Human Resources Management and Marketing. While neo-institutional organisation theory has become a new dominant approach in analysing enterprise adaption to economic transition, this theory has not been applied to demographic transition so far. The extensive literature for Western European countries as well as the US on how to cope with the demographic challenges has not referred to this theory. Moreover, so far only few studies exist that look explicitly at the demographic challenge in the CEEC. This paper intends to fill these gaps.

The paper is structured as follows. Section 2 starts with a discussion of the theoretical background and gives an overview of current and future demographic and economic developments. Section 3 then discusses the implications for Human Resources Management. Section 4 focuses on the Marketing implications. Section 5 concludes.

\section{The demographic and economic transition}

\subsection{Theoretical background}

This paper builds on the neo-institutional organisation theory in the macro-level research tradition. This theoretical lens has been widely used to study the adoption of organisational forms and practices in general (Kostova/Roth 2002; Björkman/Fey/Park 2007; Beck/Walgenbach 2009), also specifically in the context of economic transition (Hoskisson et al. 2000; Meyer/Nguyen 2005; Karhunen 2008). The basic thesis of neo-institutional organisation theory is that organisations are under social influences and pressures to adopt forms and practices that are viewed as being appropriate for the situation (DiMaggio/Powell 1983/1991). These pressures result from fundamental 
institutions in form of generally accepted norms and values within each society, embodying expectations of how organisations should be designed and what purposes they should fulfil (Lawrence 1999). Organisations that adapt to these pressures are more likely to attain legitimacy, obtain scarce resources and have higher survival chances (Meyer/Rowan 1977). As a consequence organisations operating in a similar societal environment or "organisational field" (DiMaggio/Powell 1983: 148) become isomorphic with other organisations in their institutional setting over time, i.e. they become more and more similar in behaviours and structures. The emphasis is placed on three types of institutional isomorphism (DiMaggio/Powell 1983): coercive isomorphism, where a powerful constituency such as the government imposes certain patterns on the organisation (e.g. new legislation); mimetic isomorphism, where organisations in situations of uncertainty model themselves after other organisations that they consider to be more legitimate or successful; and normative isomorphism, where professional organisations (e.g. consulting firms, universities, professional networks) act as the disseminators of appropriate organisational forms and practices. More recently, Scott (2001) has suggested three corresponding pillars of institutional processes: regulative (cf. coercive), cognitive (cf. mimetic) and normative processes.

In transition economies, as long as the institutional context itself is in flux, these three types of isomorphic pressures are weak (Karhunen 2008) and the institutional context does not provide enterprises with well-established templates of organising (Newman 2000). As transition proceeds, the institutional pressures gain strength and result in new templates of organising (Karhunen 2008). In terms of Tolbert and Zucker (1996), organisational structures during transition can be classified as being at the pre-institutionalisation stage. While transition proceeds, objectivation and sedimentation of structures lead to semi- and to fullinstitutionalisation stages.

In this paper we extend the application of the neo-institutional organisation theory to demographic transition. We argue that the demographic change generally will be a central institutional pressure forcing companies to adapt their organisational forms and practices in particular in two distinct areas: Human Resources Management and Marketing. Due to the combination of economic transition and the comparably rapid aging and shrinking of the population compared to Western Europe, the CEEC will face these pressures earlier and with a bigger intensity.

The theoretical model of the paper is based on Meyer and Rowan's (1977) seminal paper (see Figure 1). As we will explain in chapter 2.2 und 2.3 the demographic and economic transition has lead and will lead to a societal modernisation resulting in the prevalence of new institutional elements such as changed values and expectations of employees and consumers. These elements in turn will strongly influence the elaboration of new organisational structures 
and practices in order to achieve conformity with these institutional processes. In chapter 3 and 4 we discuss and suggest such organisational measures for Human Resources Management and Marketing. Through such organisational measures organisations maximise their legitimacy, obtain scarce resources like the top-skilled labour force and ensure their survival.

\section{Figure 1. Theoretical model}

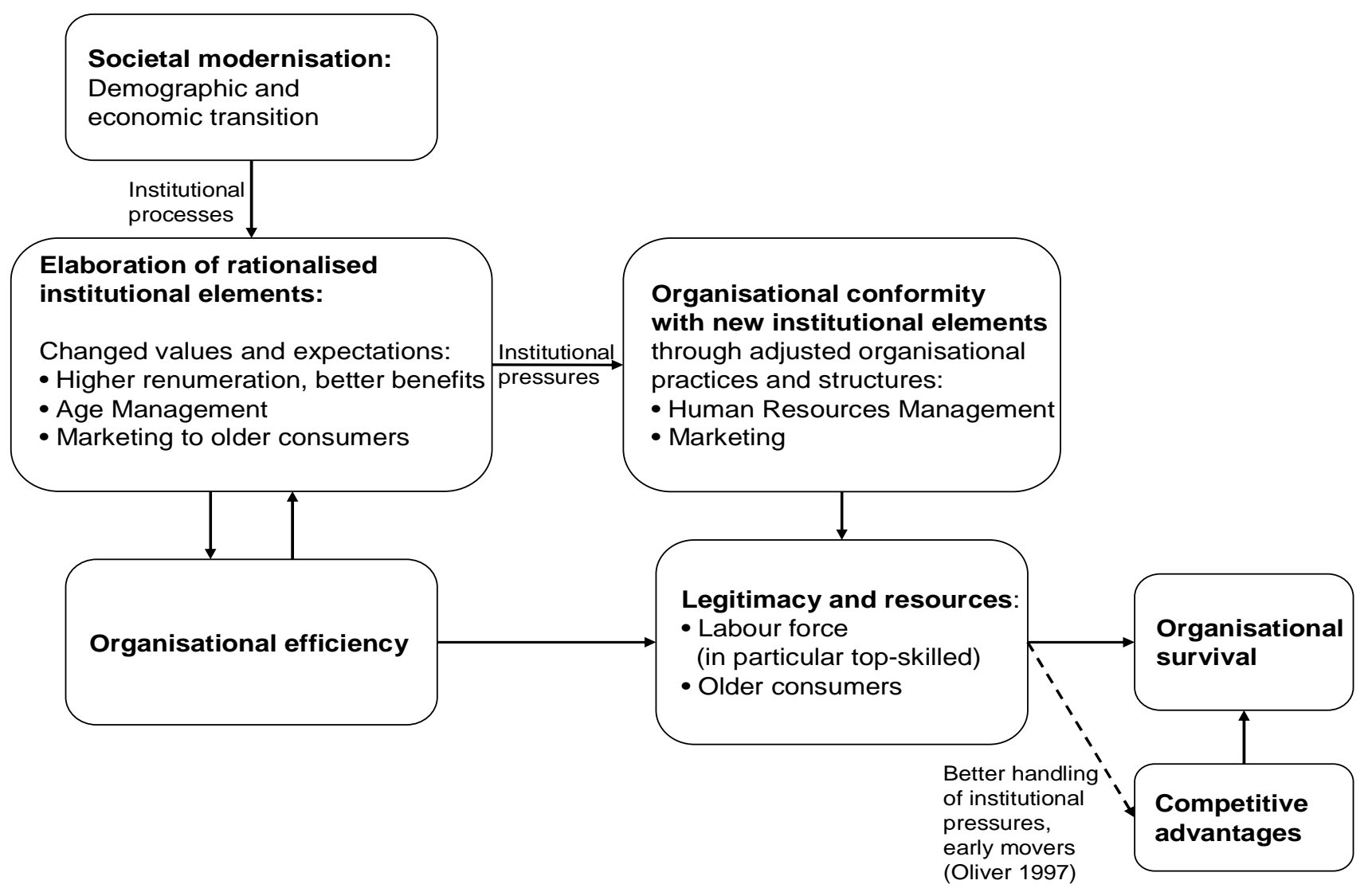

Source: Authors' adaption of Meyer/Rowan $(1977: 346,353)$ to demographic and economic transition.

The demographic transition has also parallels with economic transition, the institutional context itself is in flux. Hence, based on the arguments and results of Karhunen (2008) it can be expected that the three types of institutional isomorphism are also weak at the first phases of transition and gain strength as transition proceeds. Organisational structures and forms developed to cope with transition need objectivation and sedimentation; and institutionalisation can be expected to gradually evolve. Since the demographic development can be projected with a comparably low degree of uncertainty, this offers chances for companies reacting early to these predictable institutional pressures. As pointed out by Oliver (1997), firms that are better at handling institutional pressures may attain a competitive advantage (see Figure 1). Referring to the three pillars of 
institutional processes (Scott 2001) such a competitive advantage could be based on regulative, cognitive and normative capital (Bresser/Millonig 2003).

The following sections provide a comprehensive synopsis of the institutional pressures due to demographic and economic transition, before discussing Human Resources Management and Marketing strategies in reaction to these pressures.

\subsection{Demographic development}

The demographic profile of the CEEC differs significantly from Western members of the European Union (Dickmann 2004). Although the CEEC can be grouped together their demographic development is not homogenous and each of them has its particularities (Schaich 1998). The population in CEE is younger on average than Western European countries with a median age of 37.5 (weighted average) compared to e.g. 42.1 in Germany (2005). However, some countries like Slovenia (40.2) and Latvia (39.3) are relatively old, while others like Slovakia (35.6) and Poland (36.8) still have very young populations. For the future, however, the median age in the CEEC is projected to increase to 51.2 (weighted average) until 2050, compared to e.g. 49.4 in Germany (United Nations (ed.) 2007, medium variant). In contrast to the EU-15 all eight CEEC will in addition face a negative population growth (see Table 1). Thus, the CEEC will both dramatically age and shrink in the coming decades.

Table 1. Total population and old-age dependency ratios in CEEC

\begin{tabular}{|c|c|c|c|c|c|c|}
\hline & \multicolumn{2}{|c|}{ Total population in millions } & \multicolumn{3}{c|}{ Old-age dependency ratio } \\
\hline & $\mathbf{2 0 0 4}$ & $\mathbf{2 0 5 0}$ & $\begin{array}{c}\text { Percental } \\
\text { change }\end{array}$ & $\mathbf{2 0 0 3}$ & $\mathbf{2 0 5 0}$ & $\begin{array}{c}\text { Change 2003- } \\
\mathbf{5 0}\end{array}$ \\
\hline EU-15 & 382.7 & 388.3 & 1 & 25 & 52 & 26 \\
\hline $\begin{array}{c}\text { Czech } \\
\text { Republic }\end{array}$ & 10.2 & 8.9 & -13 & 20 & 55 & 35 \\
\hline Estonia & 1.4 & 1.1 & -17 & 23 & 43 & 20 \\
\hline Hungary & 10.1 & 8.9 & -12 & 22 & 48 & 26 \\
\hline Latvia & 2.3 & 1.9 & -19 & 23 & 44 & 21 \\
\hline Lithuania & 3.4 & 2.9 & -16 & 22 & 45 & 23 \\
\hline Poland & 38.2 & 33.7 & -12 & 18 & 51 & 33 \\
\hline Slovakia & 5.4 & 4.7 & -12 & 16 & 51 & 34 \\
\hline Slovenia & 2.0 & 1.9 & -5 & 21 & 56 & 35 \\
\hline
\end{tabular}

Source: Economic Policy Committee (2005a:15 and 23).

This is nicely illustrated by the change in the shape of the population pyramid. By 2050, the pyramid for most of the CEEC will have the structure of a rectangle or even an inverted pyramid (see Figure 2). The old-age dependency 
ratios (OADR $)^{1}$ are projected to increase significantly. Still, their level is projected to remain below EU-15 average for most of the countries (see Table 1) since today's OADRs are comparably low. But the speed with which they will increase is enormous. This development supports the thesis of weak institutional isomorphism in the first phase which is gaining strength while transition proceeds (Karhunen 2008).

Figure 2. Population pyramids of the eight CEEC

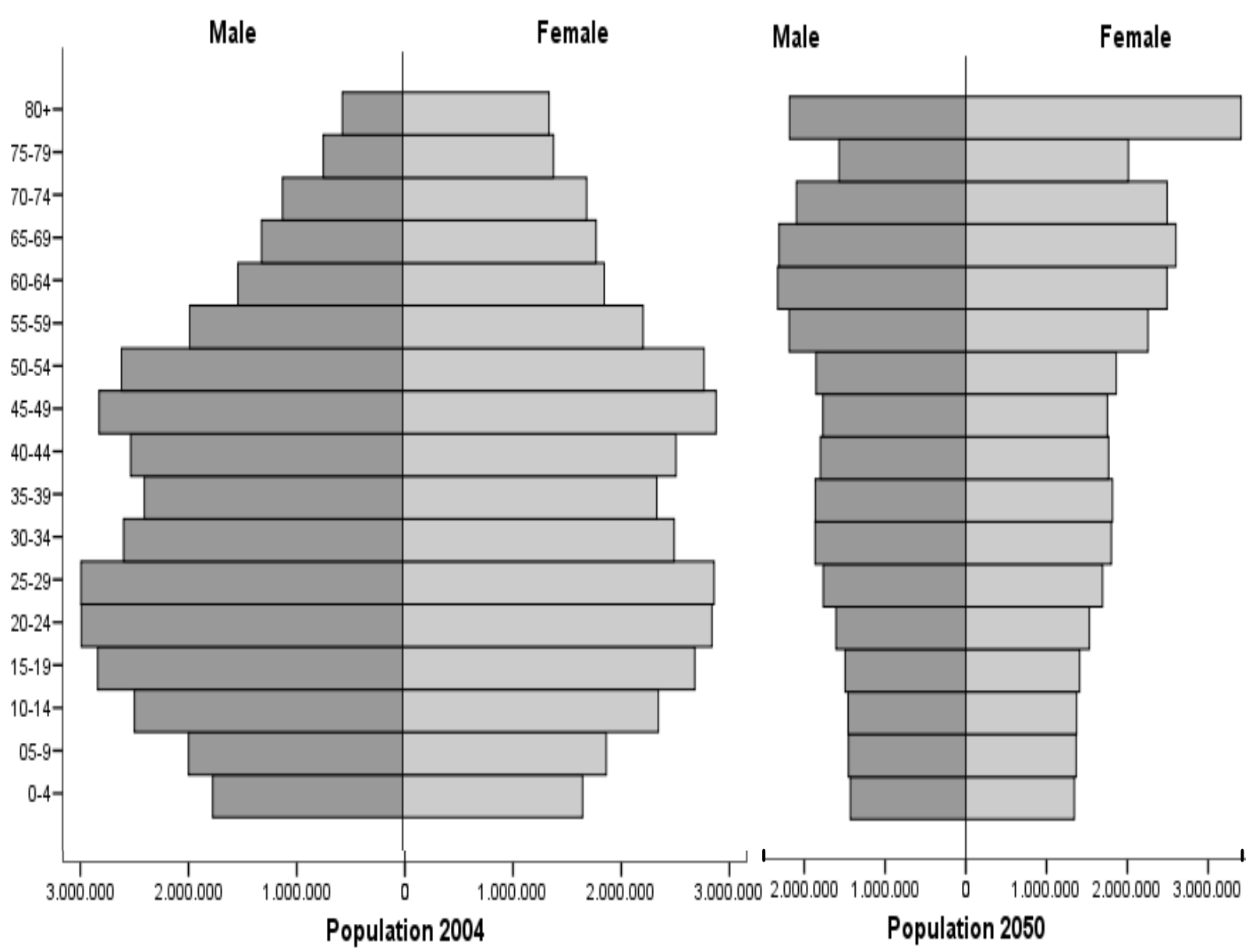

Source: Authors' calculations and compilations based on the Eurostat EUROPOP2004 baseline scenario.

This population development results from changes in three parameters, namely fertility rates, life expectancy (and accordingly mortality) and migration. In the following we will briefly describe the past and future population developments for the CEEC.

1 Population aged 65 and over as percentage of population aged 15-64. 
Fertility. During the early 1980 s the total fertility rates in the CEEC were above the rates in Western Europe; it was common for women to marry early and have children in their mid-twenties (Dickmann 2004). Before the economic transition a household with two children was the normal case. However, during the 1990s the fertility rates in CEEC decreased rapidly below 2.1 (see Table 2), which is the necessary rate to keep the population constant. In 2004 the fertility rates were even well below the EU-15 average of 1.53: between 1.1 in the Czech Republic and 1.39 in Estonia. These low fertility rates were caused by very different reasons (Pohl 2004). First and foremost, the economic recession led to a collapse of the pro-natal population policy at the beginning of the 1990s so that women were faced with the conflict between motherhood and work (UNECE 2000). Second, guaranteed labour disappeared, unemployment and impoverishment rose significantly, leading to an increase in the economic uncertainty of individuals and their families. Third, the economic uncertainty was accompanied by uncertainty due to the societal transformation and the weak laws and institutions during the adjustment period. As a consequence, family formation was postponed or even rejected (Philipov 2001). In addition, the collapse of the totalitarian regimes also opened the way for ideational changes towards Western European values like higher individualism. Finally, more people opted for a higher and more desirable education which increases the opportunity costs of child raising (Philipov/Dorbritz 2003). By 2050 the fertility rates are projected to reach the EU-15 average of approximately 1.6 in most of the countries (see Table 2).

Table 2. Fertility and life expectancy in CEEC

\begin{tabular}{|c|c|c|c|c|c|c|c|c|}
\hline & \multicolumn{4}{|c|}{ Total fertility rates } & \multicolumn{3}{c|}{ Life expectancy at birth for males } \\
\cline { 2 - 9 } & $\mathbf{1 9 8 8}$ & $\mathbf{1 9 9 5}$ & $\mathbf{2 0 0 4}$ & $\mathbf{2 0 5 0}$ & $\mathbf{1 9 8 8}$ & $\mathbf{1 9 9 5}$ & $\mathbf{2 0 0 4}$ & $\mathbf{2 0 5 0}$ \\
\hline EU-15 & 1.59 & 1.42 & 1.53 & 1.61 & 72.5 & 73.9 & 76.4 & 82.1 \\
\hline $\begin{array}{c}\text { Czech } \\
\text { Republic }\end{array}$ & 1.94 & 1.28 & 1.15 & 1.50 & 68.1 & 69.7 & 72.4 & 79.7 \\
\hline Estonia & 2.26 & 1.32 & 1.39 & 1.60 & n.a. & 61.9 & 65.5 & 74.9 \\
\hline Hungary & 1.81 & 1.58 & 1.30 & 1.60 & 66.2 & 65.3 & 68.5 & 78.1 \\
\hline Latvia & 2.16 & 1.26 & 1.30 & 1.60 & 66.3 & 60.3 & 64.9 & 74.3 \\
\hline Lithuania & 2.02 & 1.55 & 1.29 & 1.60 & 66.2 & 63.3 & 66.5 & 75.5 \\
\hline Poland & 2.13 & 1.61 & 1.21 & 1.60 & 67.2 & 67.6 & 70.5 & 79.1 \\
\hline Slovakia & 2.15 & 1.52 & 1.19 & 1.60 & 67.1 & 68.4 & 69.7 & 77.7 \\
\hline Slovenia & 1.63 & 1.29 & 1.18 & 1.50 & 68.9 & 70.3 & 72.6 & 79.8 \\
\hline
\end{tabular}

Sources: Economic Policy Committee (2005a:10 and 12), for 1988 and 1995 Eurostat.

Life expectancy. In many CEEC life expectancy, which is "a concise indicator of the overall level of mortality" (Philipov/Dorbritz 2003:125), remained roughly constant or even decreased for males and increased very slowly for females from the mid-1960s up to the end of the 1980s while it has risen constantly in Western Europe (Dickmann 2004). In the literature, these 
differences have been discussed as the "East-West life expectancy gap in Europe" (Hertzman/Kelly/Bobak (eds.) 1996). The economic transition initiated an immediate increase in some countries (e.g. Czech Republic and Poland), while in other countries like Hungary there was a first drop at the beginning of the 1990s which was then followed by a rapid increase. Although life expectancy is rising, it is still below EU-15 average with still large differences among the CEEC (see Table 2). However, remaining life expectancy at age 65 is almost at EU level: in 2005 life expectancy of a 65 year old Pole was 16.7 years compared to 18.7 years in Germany (source: Eurostat).

Migration. Migration was strictly regulated by the Communist regimes, specific migration systems existed restricting access to the West. Only former Yugoslavia, Poland and Hungary permitted limited migration for work. A higher degree of freedom of movement existed among the Socialist countries. The collapse of the Eastern Bloc initiated stronger migration flows at the beginning of the 1990s which decreased over the decade (United Nations (ed.) 2002). Migration varied widely in some countries (Poland, Estonia, Latvia) showing strong negative net migration while others (Czech Republic, Slovakia and Hungary) had almost constant migration gains. In Poland the majority was eastwest migration to Germany and the USA, while the emigration losses of the Baltic countries were predominantly due to remigration of ethnic Russians to the Russian federation. The Czech and Slovak Republic were linked by migration and the net gains primarily had statistical reasons (no deregistration). The gains of Hungary were mainly based on immigration from Romania (Philipov/Dorbritz 2003). For the future (2004-2050) net immigration into the eight CEEC is projected to equal 2.2 million people, of which Hungary and the Czech Republic are expected to attract the bulk ( 0.8 and 0.6 million respectively) (Economic Policy Committee 2005b:34).

\subsection{Economic development}

The economic transition lead to powerful regulative institutional processes (Scott 2001) like deep changes in the labour market. In addition, the change in the political regime also brought about fundamental reforms of the social security systems. Even though having been only recently reformed, the sustainability of these systems is again threatened by the demographic projections in many CEEC. Soaring contribution rates to social security systems in turn invoke strong negative incentive effects on the labour market. In the following, we will briefly depict the main changes on the labour market as well as the main developments in the reforming of pension systems as one very important branch of the social security systems in that they largely determine people's income in old-age.

Labour Market. High labour force participation rates and virtually nonexistent unemployment were key features of the Soviet-style socialism. Full employment 
was achieved through overstaffing. The restructuring of the business sector during the economic transition led to a drop in output and substantial job losses, which were concentrated during the first phase of the transition (until the mid1990s) and continued at a much slower pace afterwards (Rutkowski 2006b). Due to the dramatic decrease in the number of jobs, unemployment rose and labour force participation fell. Many displaced and discouraged took also advantage of early retirement as an alternative to unemployment. Thus, employment rates declined dramatically (by 20 to 30 percent) during the 1990s (Rutkowski 2006b). Despite apparently similar initial conditions at the beginning of the transition, unemployment rates now vary strongly across the eight CEEC. In Poland for example the unemployment rate was about 2.5 times higher than in Hungary and in Slovakia the unemployment rate was twice as high as in the Czech Republic in 2005 (see Table 3). Youth unemployment differs substantially as well, especially in Poland and Slovakia it is an issue of particular concern with rates exceeding 30 percent.

Table 3. Employment, unemployment and labour force participation 2005

\begin{tabular}{|c|c|c|c|c|}
\hline & Employment rate & $\begin{array}{c}\text { Unemployment } \\
\text { rate }\end{array}$ & $\begin{array}{c}\text { Labour force } \\
\text { participation rate }\end{array}$ & $\begin{array}{c}\text { Youth } \\
\text { unemployment } \\
\text { rate }\end{array}$ \\
\hline EU-15 & 65.2 & 7.9 & 71.0 & 16.7 \\
\hline $\begin{array}{c}\text { Czech } \\
\text { Republic }\end{array}$ & 64.8 & 7.9 & 70.4 & 19.2 \\
\hline Estonia & 64.4 & 7.9 & 70.1 & 15.9 \\
\hline Hungary & 56.9 & 7.2 & 61.3 & 19.4 \\
\hline Latvia & 63.3 & 8.9 & 69.6 & 13.6 \\
\hline Lithuania & 62.6 & 8.3 & 68.4 & 15.7 \\
\hline Poland & 52.8 & 17.7 & 64.4 & 36.9 \\
\hline Slovakia & 57.7 & 16.3 & 68.9 & 30.1 \\
\hline Slovenia & 66.0 & 6.5 & 70.7 & 15.9 \\
\hline
\end{tabular}

Source: European Commission (2006: 258-281).

Labour force predictions have two components, a demographic projection (working age population) and assumptions on labour force participation rates, which are policy related (Börsch-Supan 2004). We already described the demographic projections in section 2.1. Labour force participation rates are expected to increase strongly until 2025 and to decrease moderately from 2025 until 2050 (see Table 4). In the medium term (until 2025) half of the countries are projected to record an increase in labour supply (especially Poland and Slovakia) while the others are expected to record a decrease (see Table 4). During the second period (2025-2050) the labour force is expected to decline significantly in all CEEC. Since labour force participation rates are projected to decrease only moderately, the labour force reduction can be ascribed almost exclusively to the underlying demographic development. 
Table 4. Labour force and participation projections

\begin{tabular}{|c|c|c|c|c|c|c|c|c|}
\hline & \multicolumn{3}{|c|}{$\begin{array}{c}\text { Labour force participation } \\
\text { rates }\end{array}$} & \multicolumn{5}{c|}{ Labour force projections } \\
\cline { 2 - 10 } & $\begin{array}{c}\text { Changes } \\
\mathbf{2 0 0 3 -} \\
\mathbf{2 0 2 5}\end{array}$ & $\begin{array}{c}\text { Changes } \\
\mathbf{2 0 2 5 -} \\
\mathbf{2 0 5 0}\end{array}$ & $\begin{array}{c}\text { Level } \\
\mathbf{2 0 5 0}\end{array}$ & $\begin{array}{c}\text { Level } \\
\mathbf{2 0 0 3}\end{array}$ & $\begin{array}{c}\text { Level } \\
\mathbf{2 0 2 5}\end{array}$ & $\begin{array}{c}\text { Level } \\
\mathbf{2 0 5 0}\end{array}$ & $\begin{array}{c}\text { Changes } \\
\mathbf{2 0 0 3}- \\
\mathbf{2 0 2 5}\end{array}$ & $\begin{array}{c}\text { Changes } \\
\mathbf{2 0 2 5 -} \\
\mathbf{2 0 5 0}\end{array}$ \\
\hline EU-15 & 4.6 & 1.1 & 76.1 & 178659 & 188805 & 168393 & 5.7 & -10.8 \\
\hline $\begin{array}{c}\text { Czech } \\
\text { Republic }\end{array}$ & 6.8 & -2.6 & 74.5 & 5061 & 4850 & 3744 & -4.2 & -22.8 \\
\hline Estonia & 7.2 & -1.2 & 76.1 & 642 & 605 & 511 & -5.8 & -15.6 \\
\hline Hungary & 8.0 & -2.2 & 66.4 & 4204 & 4188 & 3440 & -0.4 & -17.9 \\
\hline Latvia & 9.3 & -1.9 & 76.8 & 1101 & 1043 & 850 & -5.3 & -18.5 \\
\hline Lithuania & 9.0 & -1.9 & 77.1 & 1623 & 1626 & 1324 & 0.1 & -18.6 \\
\hline Poland & 9.8 & -2.5 & 71.0 & 16919 & 17438 & 13778 & 3.1 & -21.0 \\
\hline Slovakia & 8.1 & -4.3 & 73.9 & 2654 & 2748 & 2026 & 3.6 & -26.3 \\
\hline Slovenia & 6.7 & -0.6 & 73.4 & 943 & 950 & 782 & 0.8 & -17.8 \\
\hline
\end{tabular}

Source: Economic Policy Committee (2005b:61 and 64)

Figure 3. Pension expenditures in CEEC as a percentage of GDP

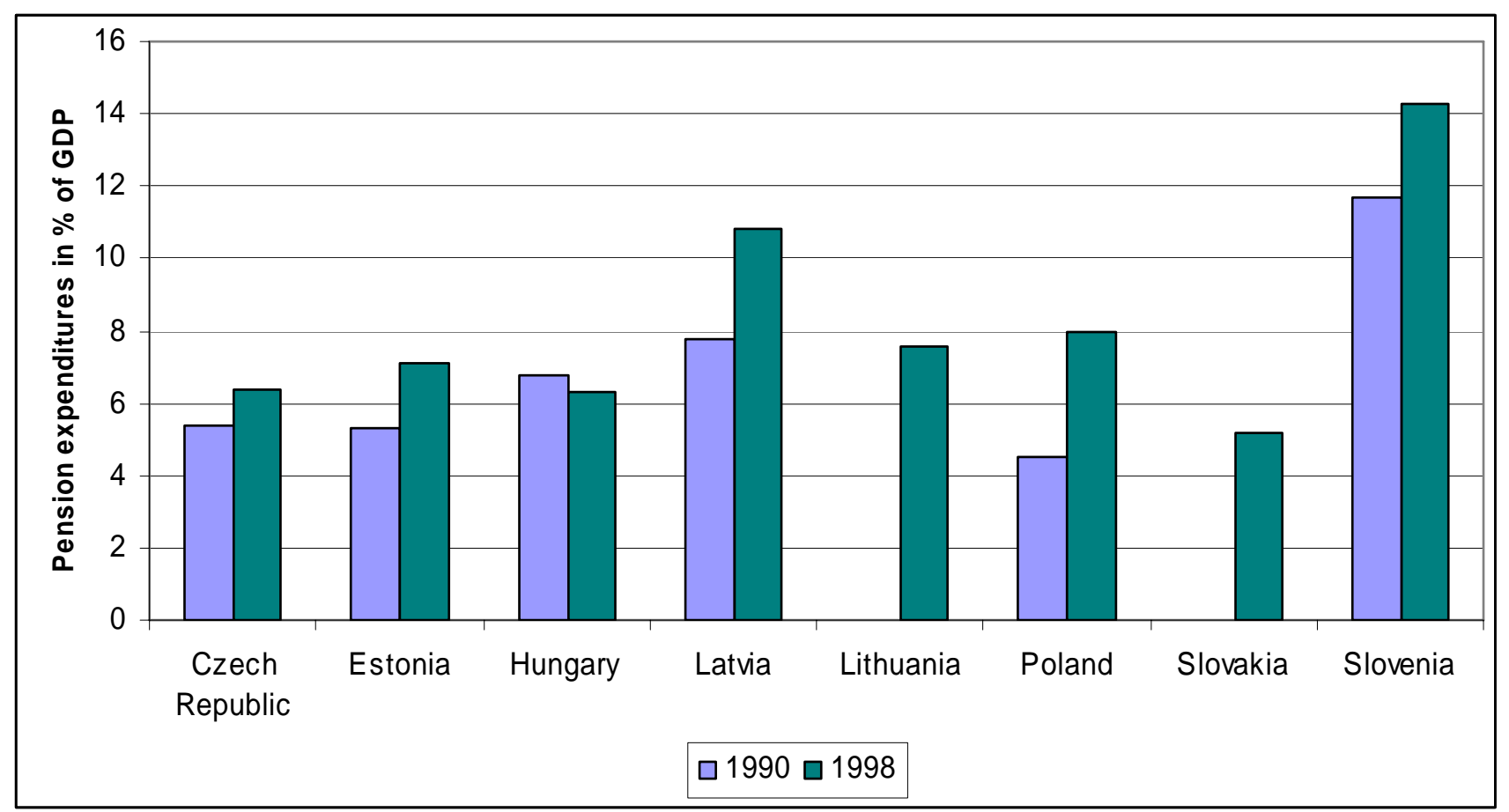

Source: Authors' compilations based on OECD (ed.) (2003:18). 1990 data for Lithuania and Slovakia is missing.

Pension system. Under the socialist regimes, public pension systems usually were administered as parts of the government budget, together with other social security branches. Cross-subsidisation was thus very common. Contributions were usually paid fully by the employer as a percentage of the total payroll. 
Thanks to high labour force participation rates, the coverage rate was almost 100 percent. The statutory retirement ages of 60 (men) and 55 (women) were low in comparison with the EU-15. Effective retirement ages were even lower. Benefits were to some extent based on the number of service years and last income, but did also include several redistributive measures and privileges for certain groups so that in the end they were only loosely linked to contribution histories. Since there was no indexation of benefits to the development of wages or inflation, they often substantially lost their purchasing power over the pension period. As a consequence, many pensioners continued to work in side jobs even though they were officially retired (Fultz/Ruck 2001; Müller 2003).

Figure 4. System dependency ratios in CEEC before and during the economic transition

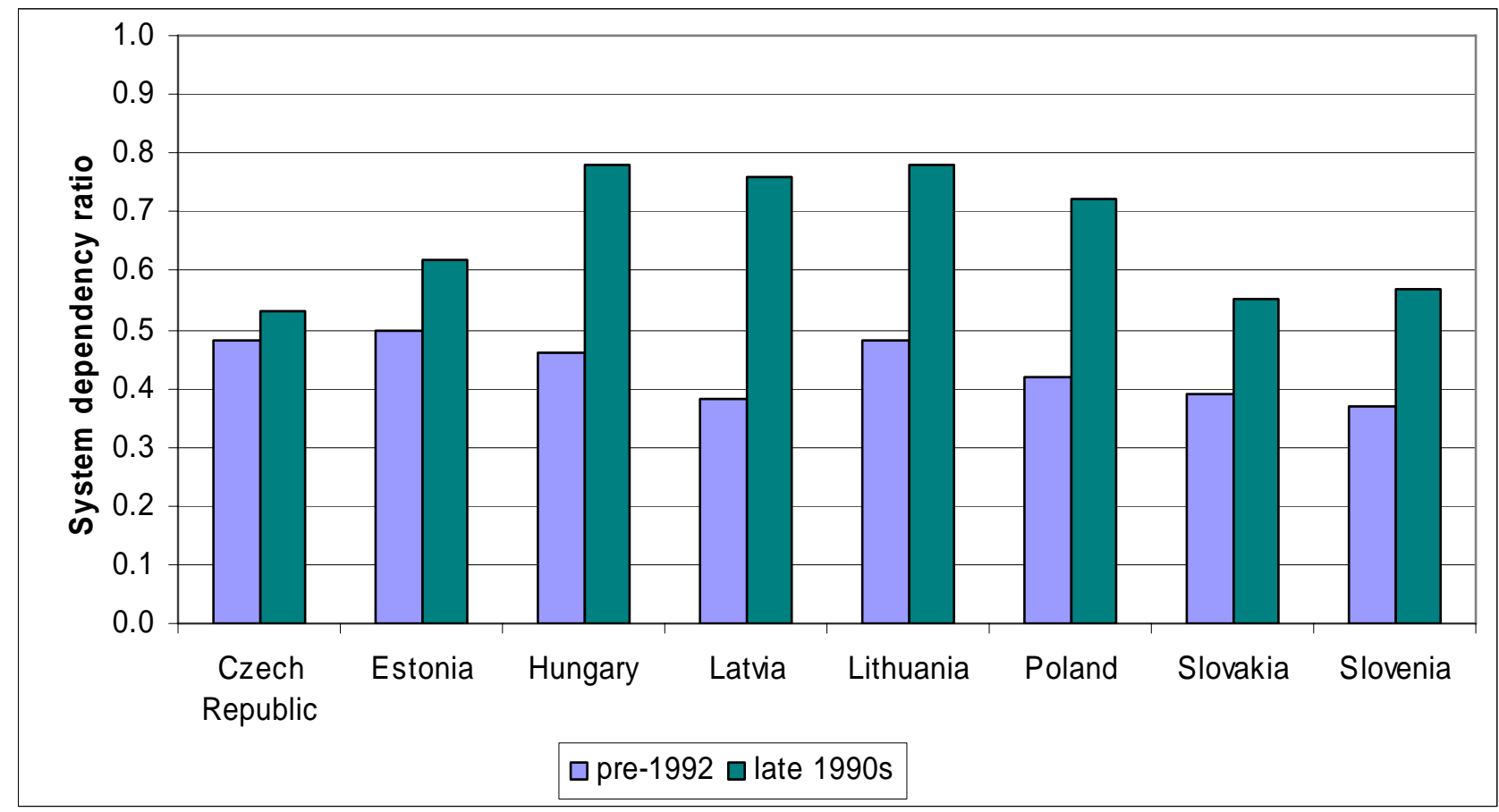

Source: Authors' compilations based on Fultz/Ruck (2001:26).

With the end of the socialist regimes and the transition to market economies in the early nineties, labour force participation rates declined while parts of the working age population emigrated to Western Europe. This has led to a considerable reduction in the contribution base of the public pay-as-you-go (PAYG) pension systems in most CEEC. At the same time, continuous increases in life expectancy as well as the partial shifting of unemployed workers into early retirement have substantially prolonged pension phases and increased pension expenditures (see Figure 3). 
Table 5. General framework of reformed pension systems in CEEC and start year of reforms

\begin{tabular}{|l|c|c|c|}
\hline Pillars & $\begin{array}{c}\text { 1. Structure of } \\
\text { PAYG pillar }\end{array}$ & $\begin{array}{c}\text { 2. Introduction of } \\
\text { mandatory } \\
\text { funded schemes }\end{array}$ & $\begin{array}{c}\text { 3. Introduction of } \\
\text { voluntary } \\
\text { funded schemes }\end{array}$ \\
\hline $\begin{array}{l}\text { Czech } \\
\text { Republic }\end{array}$ & DB (NDC by 2010) & Yes ${ }^{1)}$ & 1994 \\
\hline Estonia & DB & 2002 & 1998 \\
\hline Hungary & DB & 1998 & 1994 \\
\hline Latvia & NDC (since 1996) & 2001 & 1998 \\
\hline Lithuania & DB & 2004 & 2000 \\
\hline Poland & NDC (since 1999) & 1999 & 1999 \\
\hline Slovakia & DB & 2005 & 1996 \\
\hline Slovenia & DB & $1999^{2)}$ & 2000 \\
\hline
\end{tabular}

Source: Authors' compilations based on Dupont (2004:64).

Notes: 1) No information about start year available.

2) Exists for specific professions.

$\mathrm{DB}=$ Defined benefit system

NDC $=$ Notional defined contribution system

As a consequence, the systems' dependency ratios ${ }^{1}$ worsened rapidly (see Figure 4) and public PAYG pension systems were driven into great financial distress. In addition to these imminent pressures, it became clear that the CEEC would face further demographic challenges in the future once the extremely low fertility rates during the period of economic transition had a noticeable impact on the size of the working age population in about ten to twenty years. This led to a wave of pension reforms in the 1990s. While some countries such as Hungary, the Czech Republic and Latvia undertook their first reform measures already in the early and mid 1990s, most CEEC did not induce their first reform steps until the late 1990s or even later (see Table 5).

Parametric reforms. In most CEE countries, as a first step, parametric reform measures were taken in order to correct the numerous shortcomings of the old system. Even though the specific parametric reform measures vary greatly across CEEC, an overall pattern can be observed. First of all, public pension systems were detached from other social security branches and assigned separate budgets. Contributions which formerly had been paid solely by employers were now levied both on employers and employees (with the exception of Estonia) and many privileges as well as redistributional rules were abolished in order to link benefits more closely to contributions. Finally, statutory retirement ages for

1 The system dependency ratio describes the number of pensioners over the number of contributors to the system. 
both men and women were raised (see Table 6), adjustment factors for early retirement were introduced and eligibility criteria tightened (GVG (ed.) 2002).

However, many necessary parametric reforms within the first PAYG pillar were put on hold (e.g. in Hungary) and privileges for certain industries still persist in many countries. In Poland a reform of the fully subsidized agricultural sector was not even tried (Müller 2003). Despite considerable increases, statutory retirement ages in the CEEC are still low compared with the EU, even though remaining life expectancies are almost the same. Given that also in the rest of the EU retirement ages will need to increase further along with increases in participation rates of older workers, further adjustments will become necessary. Thanks to the tightening of eligibility criteria and the introduction of adjustment factors, the trend of early retirement however is slowing down and effective retirement ages are increasing.

Table 6. Development of statutory retirement ages in CEEC

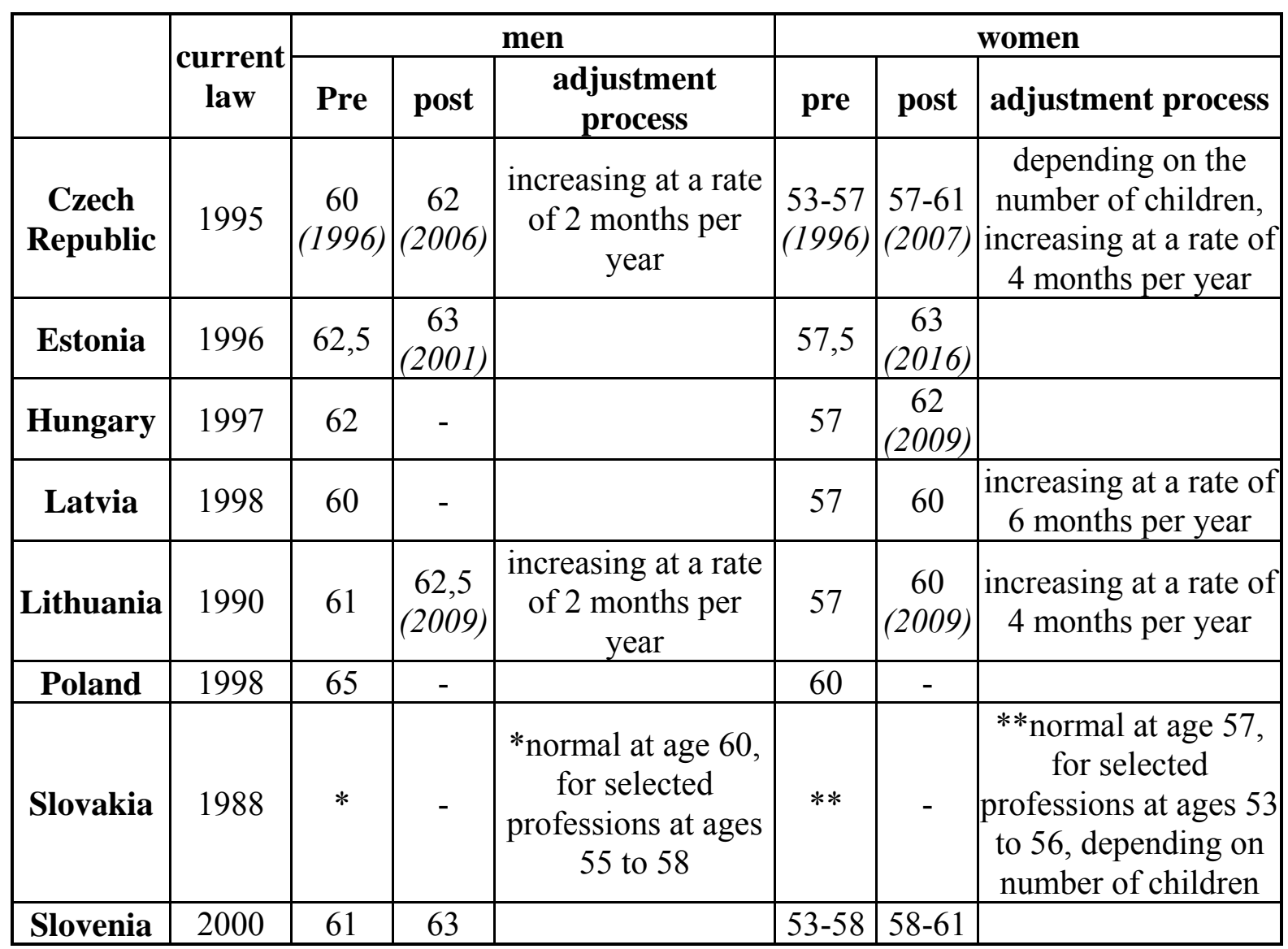

Source: Authors' compilations based on Fultz/Ruck (2001:30).

From PAYG to funded systems. On top of these parametric reforms, most CEEC followed the advice by the World Bank (1994) to introduce a supplementary funded pillar to the existing PAYG pillar in order to be better able to cope with the upcoming demographic pressures. In contrast to PAYG 
systems, funded systems can increase savings and investments in an economy and thereby provide better growth prospects.

Table 7. Contribution rates to the 1. and 2. pillar in percent of insured wage in CEEC

\begin{tabular}{|c|c|c|c|c|c|c|}
\hline & \multicolumn{2}{|c|}{ 1. PAYG Pillar } & \multicolumn{4}{|c|}{ 2. (Mandatory) Funded Pillar } \\
\hline & Employer & Employee & Employer & Employee & $\underset{2)}{\text { Coverage }}$ & Mandatory or voluntary \\
\hline $\begin{array}{c}\text { Czech } \\
\text { Republic }\end{array}$ & 19.5 & 6.5 & & & $40^{3)}$ & $\begin{array}{l}\text { Mandatory for workers } \\
\text { below } 18 \text { years of age } \\
\text { and optional for other } \\
\text { workers }\end{array}$ \\
\hline Estonia & \begin{tabular}{|c|}
$20\left(16^{*}\right.$ if \\
participation \\
in 2. Pillar $)$
\end{tabular} & 0 & 4 & 2 & 60 & $\begin{array}{c}\text { Mandatory for new } \\
\text { entrants to labour market } \\
\text { and optional for other } \\
\text { workers } \\
\end{array}$ \\
\hline Hungary & 18 & 8 & 6 & & 45 & \begin{tabular}{|c|} 
Mandatory for workers \\
below 30 years of age \\
and optional between the \\
ages of 40 and 49 \\
\end{tabular} \\
\hline Latvia & \begin{tabular}{|c|}
27.1 for old \\
age \\
pensions \\
and 3.76 for \\
disability \\
pensions \\
(paid by the \\
state) \\
\end{tabular} & 0 & $\begin{array}{l}2 \\
\text { increasing } \\
\text { to } 10 \text { until } \\
2010\end{array}$ & & 72 & \\
\hline Lithuania & 22.5 & 2.5 & & & & \begin{tabular}{|c|} 
Mandatory for workers \\
below 30 years of age \\
and optional between the \\
ages of 30 and 49 \\
\end{tabular} \\
\hline Poland & 16.26 & 16.26 & 7.3 & & 70 & \\
\hline Slovakia & $21.6^{1)}$ & $5.9^{1)}$ & & & & \\
\hline Slovenia & 8.85 & 15.5 & & & & \\
\hline
\end{tabular}

Sources: Authors' compilations based on GVG (ed.) (2002: 26 and 54).

Notes: 1) See Fultz/Ruck (2001:33).

2) See OECD (ed.) (2003:19-20).

3) See Holzmann/Orenstein/Rutkowski (eds.) (2003).

Furthermore, their introduction is to facilitate the formation of efficient capital markets - an important aspect for the CEEC where no complete capital markets existed under the socialist regimes. Moreover, government influence on funded systems is more limited. Mixed pension systems based on both a PAYG and a funded pillar are therefore likely to better diversify political, demographic and capital market risks. Last but not least, funded systems strengthen the link 
between individual contributions and benefits since every individual builds up his own capital stock for retirement. Contributions should therefore in general be perceived as such and not as taxes, reducing the incentives to drop out of the system.

In most CEEC, contributions to the supplementary funded pillar are mandatory for younger workers while older workers can often still choose whether they want to redirect parts of their contributions to the new system or not. Contribution rates vary between 2 and 10 percent and are typically paid by the employer (see Table 7). In Latvia and Poland, more than two thirds of the workforce is already under the coverage of the new funded pillar, while it is still less than half in the Czech Republic and Hungary.

Within the supplementary funded schemes, the performance of pension funds has been rather poor so far. In most CEEC, funds must invest the majority of their capital inside the country which leads to low risk diversification and high market concentration in countries with a small population and small capital stocks such as the Baltic states. Only a limited amount of capital may be invested into foreign capital markets. In Latvia this threshold is 15 percent, in Poland only 5 percent. In addition, rates of return are often negative in the beginning due to high administrative costs and inflation which must be subtracted upfront (front-loading problem) (Müller 2005).

Figure 5. Replacement rates in percent of average wages in CEEC

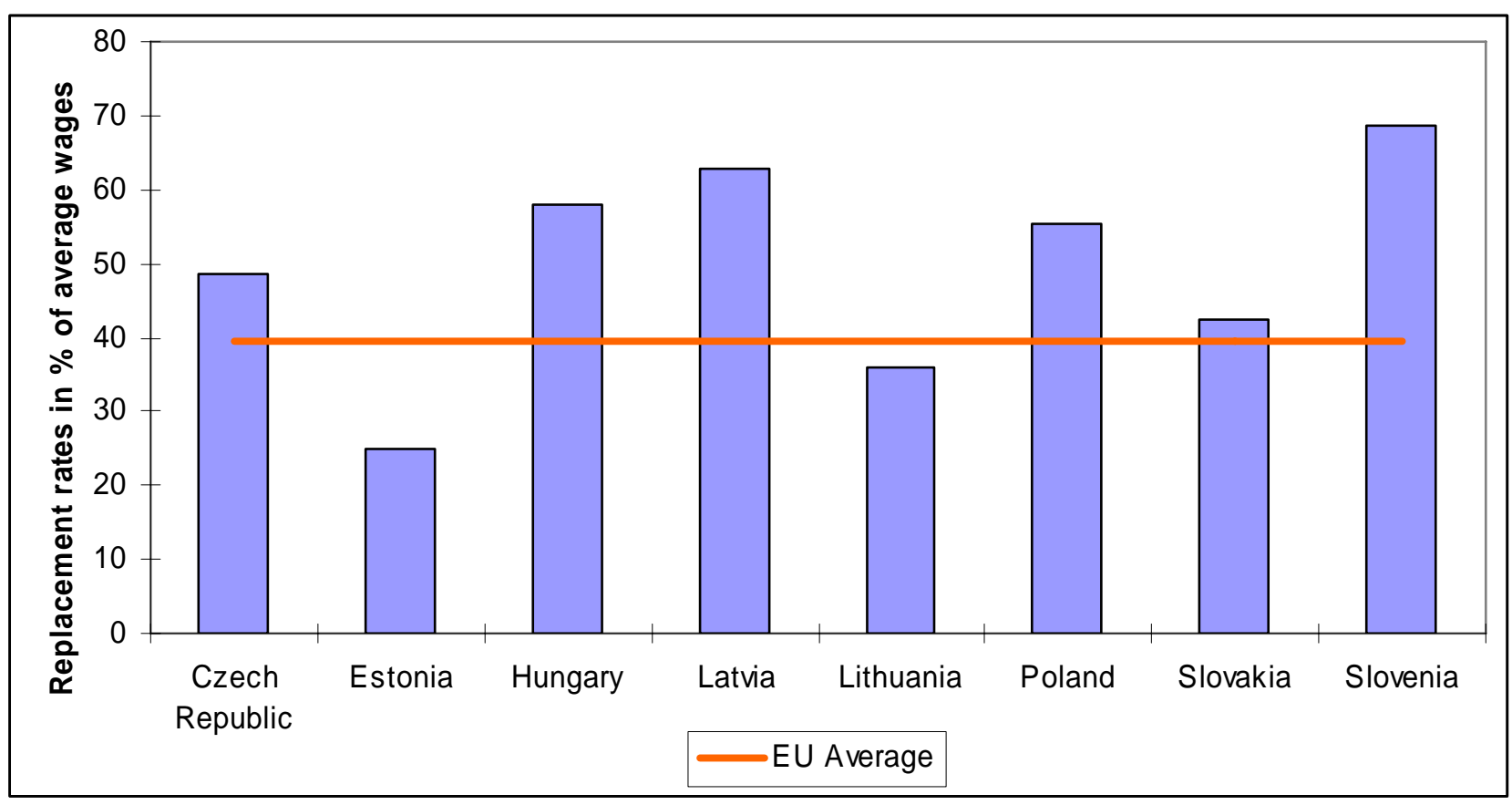

Source: Authors' compilations based on OECD (ed.) (2003).

Current outlook. Revenues of the PAYG systems continue to decline, especially since contributions are often redirected towards the supplementary 
second pillar without accompanying increases in the overall contribution rate. The enormous rise in pension costs seems to have come to a halt but some countries such as Estonia record alarmingly low replacement rates clearly below the EU average, which calls for revaluations of some kind (see Figure 5).

Despite these difficulties, the implemented reforms have at least induced a shift away from formerly flat and redistributive to more earnings oriented pension systems that comprise both PAYG and funded elements. For the EU as a whole, capital funded pension schemes are thus likely to play a much bigger role in European pension policy than they do today.

\section{Implications for human resources management}

The depicted demographic and economic past and future projected development will force companies to develop strategies and concepts to cope with these developments and the related institutional processes and pressures. Companies will face three major challenges: a declining labour force, an ageing workforce, and an ageing customer base. For Human Resources Management (HRM) it is mainly the first two challenges that are most relevant for new HRM policies. While the first can be coped with by strategies for the so-called "war of employees", the second problem can be addressed by an appropriate age management in the firm. Both strategies aim at gaining legitimacy in the entire labour force and ensuring attractivity for the human resources needed to survive.

\subsection{Strategies for the "war for employees"}

The labour force is projected to decline significantly (see Chapter 2.3). This will have strong consequences for companies operating in the CEEC; with a decline of 17 to 26 percent until 2050 (see Table 8) the "war for talents" will develop into a "war for employees". This can be a major challenge especially for domestic companies and Small and Medium Enterprises (SME) that cannot afford attracting employees by paying high salaries or offering expensive benefits since money and social benefits are the most important motivators (Kiriazov/Sullivan/Tu 2000; Harzing 2004). There are two ways of solving the problem of projected labour shortfalls: to boost productivity high enough or to increase labour force participation (Nyce/Schieber 2005). The latter is possible by attracting more workers into the workforce (older people, women, and foreigners) and/or convincing workers to work longer hours or to delay retirement. Therefore, an increase of retirement ages would mitigate two demographic challenges at once, the pressure on pension systems (see Chapter 0) and labour shortfalls. A good example is the so-called "work line" policy in Sweden or Denmark which aims at activating all labour force segments. The two countries not only have a good system for initial education and vocational training, but lifelong learning is also promoted through high investments, especially for poorly qualified workers (Bosch/Schief 2005). 
Since the skilled labour of CEEC is valued by multinational enterprises (MNEs) (Rutkowski 2006a), the development of the skilled labour segment is of particular importance for the future of the CEEC. We have projected the number of enrolled students in 2025 and 2050 by calculating the ratio of students to the age group of 19-24 for 2004 (the typical age range for students in CEE) and multiplying this ratio by the projected size of the age group in 2025 and 2050 respectively. Since engineers are especially important for the innovation ability we repeated the calculations for engineers. We assumed the ratios of students to the age group and engineering students to total students to be constant, so the percentage changes are the same as for the total number of students. The results are even more alarming than the development of the total labour force (see Table 9). For all CEEC the number of enrolled students is projected to decrease sharply (between 29 and 46 percent) already until 2025.

Table 8. Changes in labour force size and age structure

\begin{tabular}{|c|c|c|c|c|}
\hline & Total change in & \multicolumn{3}{|c|}{ Demographic effect } \\
\cline { 3 - 5 } & $\begin{array}{c}\text { Labour force } \\
\text { (percent) 2003- } \\
\text { 2050 }\end{array}$ & Young (15-24) & Prime age (25-54) & Older (55-64) \\
\hline EU-15 & -5.7 & -2.2 & -13.7 & 1.3 \\
\hline $\begin{array}{c}\text { Czech } \\
\text { Republic }\end{array}$ & -26.0 & -4.8 & -26.7 & 0.1 \\
\hline Estonia & -20.5 & -5.5 & -21.4 & 0.9 \\
\hline Hungary & -18.2 & -3.8 & -23.7 & 0.1 \\
\hline Latvia & -22.8 & -6.2 & -24.7 & 0.3 \\
\hline Lithuania & -18.5 & -4.5 & -24.5 & 2.7 \\
\hline Poland & -18.6 & -7.0 & -26.0 & 2.7 \\
\hline Slovakia & -23.7 & -7.1 & -27.3 & 2.4 \\
\hline Slovenia & -17.1 & -3.8 & -24.4 & 0.8 \\
\hline
\end{tabular}

Source: Economic Policy Committee (2005b:66).

The decreases are much more pronounced than in the Western "engineering country" Germany (-16.5 percent). This could heavily affect MNEs' decision for foreign direct investments and particularly research and development (R\&D) locations, an area where CEEC like Poland and Hungary have advantages in qualifications compared to countries like India and China (UNCTAD (ed.) 2005). The competition to attract top-skilled employees will intensify further, particularly because employees in the CEEC show low loyalty to their employer and view periodic job changes as a means of obtaining pay raises and promotions (Kiriazov/Sullivan/Tu 2000). Due to an increase in value of employees when being employed by a MNE (Rutkowski 2006a) and the possibility of MNEs to offer higher salaries and better benefits, domestic firms could be crowded out from the top-skilled labour market segment. In order to mitigate this problem, the CEEC should try to increase skilled labour by 
developing their education systems or by attracting skilled immigrants. Possible strategic options for companies are to recruit more elder and foreign employees, to intensify the contact to universities and schools in order to get earlier in contact with potential employees and to engage in labour piracy combined with defensive measures (Grund 2006).

A good starting point is an analysis of the current age and qualification structure in a company and a projection of the future workforce profile in five to fifteen years. With such an analysis bottle necks in qualifications can be detected early and the company can react in a timely manner in form of human resources development measures and recruitment strategies (Adenauer 2005).

Table 9. Projected changes in enrolled tertiary students

\begin{tabular}{|c|c|c|c|c|c|c|c|c|}
\hline & \multicolumn{5}{|c|}{ Total enrolled tertiary students } & \multicolumn{3}{|c|}{$\begin{array}{c}\text { Enrolled Engineering } \\
\text { students }\end{array}$} \\
\hline & 2004 & 2025 & 2050 & \begin{tabular}{|c|} 
Changes \\
$2004-$ \\
2025 \\
in \\
percent
\end{tabular} & \begin{tabular}{|c|} 
Changes \\
$2025-$ \\
2050 \\
in \\
percent
\end{tabular} & 2004 & 2025 & 2050 \\
\hline Germany & 2330457 & 1945577 & 1716418 & -16.5 & -11.8 & 596288 & 497810 & 439175 \\
\hline $\begin{array}{c}\text { Czech } \\
\text { Republic }\end{array}$ & 318858 & 204328 & 178469 & -35.9 & -12.7 & 108415 & 69474 & 60681 \\
\hline Estonia & 65659 & 41078 & 35749 & -37.4 & -13.0 & 11700 & 7320 & 6370 \\
\hline Hungary & 422177 & 296256 & 274385 & -29.8 & -7.4 & 92854 & 65159 & 60348 \\
\hline Latvia & 127656 & 73576 & 66633 & -42.4 & -9.4 & 19323 & 11137 & 10086 \\
\hline Lithuania & 182656 & 110880 & 104317 & -39.3 & -5.9 & 59341 & 36022 & 33890 \\
\hline Poland & 2044298 & 1108009 & 1019136 & -45.8 & -8.0 & 450198 & 244007 & 224435 \\
\hline Slovakia & 164667 & 93197 & 81008 & -43.4 & -13.1 & 46885 & 26536 & 23065 \\
\hline Slovenia & 104396 & 68341 & 64253 & -34.5 & -6.0 & 26592 & 17408 & 16367 \\
\hline CEEC-8 total & 3430367 & 1995665 & 1823950 & -41.8 & -8.6 & 815308 & 477063 & 435244 \\
\hline
\end{tabular}

Source: Authors' calculations based on Eurostat and Eurostat EUROPOP2004 baseline scenario data.

\subsection{Age Management}

Apart from the problem of a declining workforce, the ageing of the workforce is another challenge for HRM. Table 8 shows that until 2050 the size of young and prime age labour force is declining while the group of elder workers will increase. Consequently the median age in companies will rise significantly. Older workers often have to face stereotypes about their performance potential (Hedge/Borman/Lammlein 2006). Problems are particularly seen concerning their productivity, motivation and innovation ability (Becker/Bobrichtchev/Henseler 2006). However, older workers often perform as effectively as their younger counterparts, especially, when they avoid suffering 
physical and cognitive declines, have a high degree of experience and expertise, have some flexibility in how to accomplish a job, retain a high motivation, have a job with little change, receive management and co-worker support and get the appropriate job training (Hedge/Borman/Lammlein 2006). Therefore, it cannot be a solution to keep employees longer in companies without changing tasks and organisational structures.

A holistic approach in HRM is necessary to gain legitimacy in an ageing workforce and to attract the needed resources. A holistic approach focuses on the entire working life and on all age groups encompassing all HRM aspects from recruitment over development to employment exit (Naegele/Wagner 2006). A central element is to change the corporate culture towards an appreciation of experienced older employees in order to keep them motivated and to avoid early retirement (Bruch/Kunze 2007). In addition to motivation, health care is an important factor. The working environment has to be redesigned to avoid physical and mental stresses and strains for older employees (Eckardstein von 2004). Precursors in that field are again the Scandinavian countries (Bosch/Schief 2005). Recruitment policies have to be adapted; also older applicants have to be targeted in order to achieve a balanced age structure and to avoid bottle necks (Naegele/Wagner 2006). A knowledge drain with the retirement of experienced employees can be avoided by using diverse teams or tandems in form of an old and a young employee working together (Zdrowomyslaw et al. 2005). In the long-term, career progression should be changed from steady upward management careers towards more specialist careers. This allows using the experience and knowledge of older employees without overburdening them with daily executive functions. As Hedge, Borman and Lammlein (2006:158) suggest "the career of the future will involve periodic cycles of skill learning, mastery, and "reskilling" in order to transition into new positions, jobs, assignments."

Since cycles of innovations are becoming shorter, especially domestic companies and SMEs in the CEEC have to stay innovative with an ageing workforce. MNEs can react to this development by relocating R\&D to countries with a more favourable demographic structure. However, it is still an open question, how the innovation ability of an ageing society will develop (Mühlbradt/Grumbach 2005). So far, empirical evidence is sparse and comes up with mixed results; particularly the productivity of diverse teams with younger and older employees is explored only little (Börsch-Supan/Düzgün/Weiss 2005). Japan may serve as a benchmark due to its rapid ageing (Wienert 2007); so MNE's with a global R\&D presence may use experiences in Japan to better cope with ageing teams in the CEEC and may import established practices to a new institutional context.

The shortened life cycles of technologies and products also require continuous training of the workforce and lifelong learning. Up to now, many companies are 
reluctant to invest in training of older employees. Becker, Bobrichtchev and Henseler (2006) asked the German top 100 companies to what extent they deal with the ageing of their workforce. Their results show that only 25 percent of the 37 respondents qualify older employees frequently and 59 percent occasionally. Moreover, 86 percent have no interest in raising this rate.

Table 10. Best practice HRM initiatives for an Ageing Workforce in CEEC

\begin{tabular}{|c|c|}
\hline $\begin{array}{c}\text { Company and } \\
\text { country }\end{array}$ & HRM initiatives \\
\hline $\begin{array}{c}\text { PTK-ECHO, } \\
\text { Slovakia }\end{array}$ & $\begin{array}{l}\text { PTK-Echo focuses on age and gender equality in all policy measures } \\
\text { and promotes lifelong learning. For example, it offers free training } \\
\text { from its own portfolio of courses for all staff irrespective of age. } \\
\text { PTK-ECHO also grants all employees a free annual preventive } \\
\text { medical check-up, along with a one-week stay in its own health } \\
\text { facility. The age management activities have resulted in a low } \\
\text { employee turnover, improved services, and greater goodwill and } \\
\text { have increased the company's competitiveness in the Slovakian } \\
\text { market. }\end{array}$ \\
\hline $\begin{array}{c}\text { Riga Electric } \\
\text { Machine Building } \\
\text { Works (RER), } \\
\text { Latvia }\end{array}$ & $\begin{array}{l}\text { Due to a shortage of skilled metalworkers RER's HRM strategy } \\
\text { aims at extending a person's working life to the maximum and even } \\
\text { attracting back those who have already retired. } 34 \text { percent of RER's } \\
\text { workforce are older than } 55 \text { years, even } 6 \text { percent are older than } 65 \text {. } \\
\text { RER's holistic approach combines a culture of respect towards older } \\
\text { employees, active recruiting methods (age of secondary } \\
\text { importance), a range of bonuses and benefits (full annual medical } \\
\text { check-up and regular vaccinations free of charge), and mentoring } \\
\text { (training of newcomers through senior employees, who receive } \\
\text { about } 20 \text { percent extra salary for mentoring). }\end{array}$ \\
\hline Zemat, Poland & $\begin{array}{l}\text { Due to a lack of qualified ironworkers and turners Zemat trains them } \\
\text { by using experienced, older employees to help them improving their } \\
\text { skills and achieving the required qualifications. Zemat also values } \\
\text { the qualifications of former employees and keeps contact to this } \\
\text { group. The company offers them flexible employment options } \\
\text { during times when there is an unexpected increase in the number of } \\
\text { orders. This is a win-win situation since it raises Zemats flexibility } \\
\text { and also provides retired employees with new financial options and } \\
\text { gives them personal satisfaction through this appreciation. }\end{array}$ \\
\hline
\end{tabular}

Source: Based on European Foundation for the Improvement of Living and Working Conditions (2007)

Companies that react early to the demographic challenge and the related institutional processes can gain a key competitive advantage (Oliver 1997). Some companies in the CEEC have already responded to that challenge. Table 10 presents three case studies with best practice initiatives of companies that are not owned by the state or foreign companies. These case studies illustrate that it is also possible for domestic companies and SMEs in CEEC to cope with an ageing workforce. However, particularly the initiatives in the latter two case 
studies were developed as reactions to an existing shortage of skilled employees. To gain competitive advantages there is a need for pro-active concepts and strategy innovations (Perlitz 1993).

\section{Marketing}

For the implications on future Marketing strategies, it is the ageing customer base that poses the main challenge. It triggers the importance of the so-called old people's market and its partly very different composition of market segments as well as new strategies on the marketing approach to older people. Through such strategies companies can gain legitimacy in the eyes of older consumers and ensure their survival. Moreover, they can also capitalise on demographic transition.

\subsection{Old people's market}

The demographic development also leads to an ageing customer base and an increasing older consumers' market segment with a bigger share of pensioner households (see Chapter 2.1 and 0). This creates opportunities and challenges for companies serving consumer markets. Consumption behaviour changes with increasing age (see Figure 6; Lührmann 2005). Expenditures in the group "health", "foods, drinks and tobacco" and "housing, water, electricity, gas and fuels" account for a bigger share in a pensioner households' budget compared with an average household.

This shift in consumption offers growth opportunities for the food and beverage industry as well as the pharmaceutical industry. Figure 7 demonstrates the spheres of influence. The effects were initially derived for Western Europe. However, as the profile of household's expenditures in CEEC like Poland gradually becomes more similar to that in developed countries (Polish Information and Foreign Investment Agency 2006) and consumers are trying to achieve similar lifestyles (Zwierzyk 2006), comparable effects can be expected. Future older generations may also benefit from the widening of the wage distribution at the upper tail during transition. High wages have become more prevalent and also very high wages emerged, not seen under the previous regime (Rutkowski 2006b).

In comparison to younger people, people in the mature market are more heterogeneous (there is not one senior market), very convenience-orientated, less price-conscious, prefer quality and reputable brands, are more loyal, seek personal attention, complain less often when they are not satisfied with a product and invest more (Perlitz 1989; Moschis 2003). The latter is also true in CEEC like Poland. Although retired people spent less than self-employed, they spent more than employees and farmers in 2003 and their level of expenditure has recently grown by more than within any other socio-economic group 
(Zwierzyk 2006). The tendency to invest more combined with a preference for reputable brands and increased loyalty shows the success potential of a strategy which aims at gaining legitimacy in the mature market. Older persons also have more free time and use more of it for reading (Eurostat 2006).

Figure 6. Profile of consumer spending for pensioners and an average household in the Czech Republic

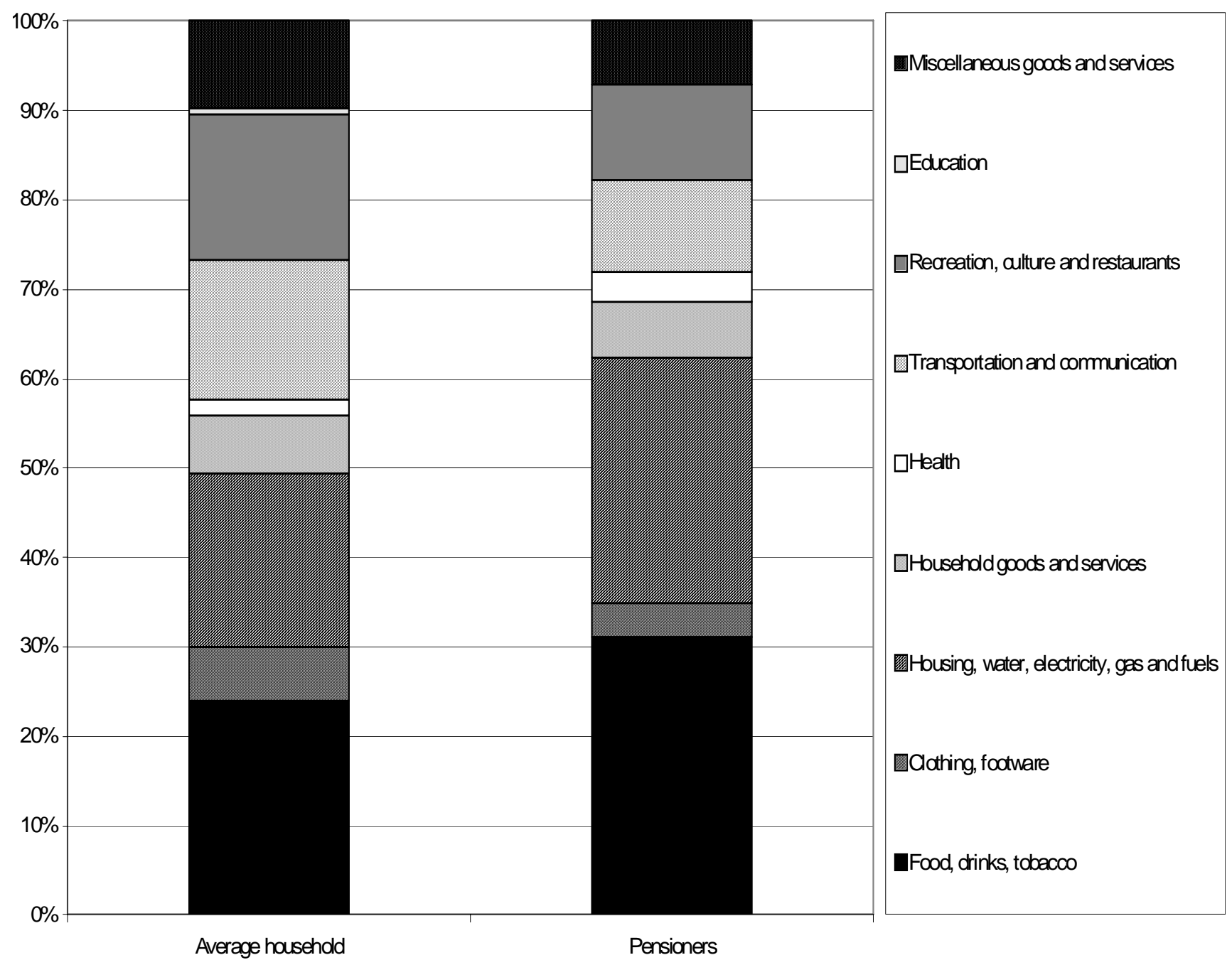

Source: Authors' compilations based on Czech Statistical Office, Household Budget Survey 2004.

\subsection{Marketing to older consumers}

These differences between older and younger people have consequences for the entire marketing mix often referred to as the four "Ps" (product, price, promotion and place). The respective four areas have to be adapted to gain legitimacy in the older consumer sector.

Older consumers need products and services solving older people's problems (Perlitz 1989). For example in the food sector, convenient, light and healthy food is needed. Thus, Nestlé Nutrition expects the biggest growth potential 
worldwide in the food sector for convenience food that is suitable for older consumers (Meyer-Hentschel 2005). Also self-medication with over the counter drugs offers opportunities. But here convenient, easy-to-open packages as well as easy to read instructions are needed. In general older consumers value convenience, functionality, quality, personalized service and products with an intergenerational or universal appeal which are not of interest exclusively to older persons (Moschis 2003; Gassmann/Reepmeyer/Walke 2005).

Figure 7. Old People's markets

\begin{tabular}{|c|c|c|}
\hline Product markets & Primary effects & Industries involved \\
\hline $\begin{array}{l}\text { Delicatessen, dietary products, } \\
\text { gourmet restaurants }\end{array}$ & & $\begin{array}{l}\text { Food industry, } \\
\text { catering industry }\end{array}$ \\
\hline $\begin{array}{l}\text { Alcoholic drinks, soft drinks, } \\
\text { coffee, tea }\end{array}$ & & Beverage industry \\
\hline Pharmaceutical products & & Chemical and life science industry \\
\hline Books, journals, magazines & & $\begin{array}{c}\text { Paper industry, } \\
\text { graphic art }\end{array}$ \\
\hline $\begin{array}{l}\text { Home improvement, garden stores } \\
\text { Recreational and hobby products }\end{array}$ & & Other manufacturing industries \\
\hline Travel clothing and products & & Clothing industry \\
\hline $\begin{array}{l}\text { Residential homes, } \\
\text { nursing homes }\end{array}$ & & Construction business \\
\hline & Secondary effects & \\
\hline
\end{tabular}

Source: Perlitz (1989:30).

Pricing decisions should take into account that seniors are less price sensitive (Pooler 2003) and prefer "à la carte pricing" compared to price bundles. Senior discounts should not be over-emphasized; old people do not want to be reminded of their age or labelled as "old" (Moschis 2003). This also affects promotion, spokespersons should be 10-15 years younger than the target group and nostalgia effects should be considered. Moreover, young and old people could be used together in a campaign to communicate the universal product appeal (Krieb/Reidl 1999).

For distribution decisions (place) a variety of methods should be considered due to the diverse segment. Only the internet is still an exemption, since only 1-10 percent of the 65-74 age group uses it in the CEEC compared to 12 percent in 
the EU-25 (Eurostat 2006). In mail order business risk aversion of seniors should be taken into account, e.g. in payment methods and through free pick-up for returns. Recommendations for traditional retail distribution include using adequate lighting, locating rest rooms easy-to-find, providing rest areas (benches or cafés) and offering rewards for long-term users (Moschis 2003).

\section{Conclusions}

The demographic change in the CEEC with a declining and ageing labour force will especially affect the top-skilled segment of the labour market. It thus requires a rethinking of public policies and company strategies. Public policy can influence the economic challenges most directly by retirement and education policies in order to utilize labour reserves (Börsch-Supan 2004). Despite considerable success in reforming the pension systems, the demographic challenge requires further reforms with a stronger shift towards capital funded pension schemes and an increase in statutory retirement ages which are still comparatively low within the EU. Concerning education a further increase in the share of well-educated young people is necessary to retain the attraction of the CEEC as R\&D location as well as the innovation ability of the societies.

For a company HRM and Marketing strategies have to be revaluated and adapted to the demographic challenge and the related institutional processes. The goal is to gain legitimacy in the labour market as well as in the older consumer sector to ensure firm survival. As the workforce declines and ages, skilled employees can increasingly be attracted only when being offered a premium in form of better remunerations or other benefits. Managers who fail to respond to that challenge in CEEC put their future growth and profitability at risk. Furthermore, companies need to get a better understanding of how older workers' needs and motivations differ from their younger counterparts. Yet the ageing of the population also offers growth opportunities as long as companies face it pro-actively. Products and services have to be developed that are aimed at solving older people's problems while having a universal appeal. Such practical, easy-to-handle products can be attractive to young people as well. Since the ageing of the population is a global phenomenon with comparable institutional processes in many countries, product and strategy innovations in reaction to that challenge could be capitalised on a global scale.

Companies and governments that respond early and energetically to the emerging demographic challenges and related institutional pressures will gain a key competitive advantage.

\section{References:}

Adenauer, S. (2005): Personalpolitik mit "demographischer Brille", in: angewandte Arbeitswissenschaft, 184, 22-39. 
Beck, N./Walgenbach, P. (229): The economic consequences of ISO 9000 Certification in East and West German firms in mechanical engineering industry, in: Journal for East European Management Studies (JEEMS), 14, 2, 166-185.

Becker, F.G./Bobrichtchev, R./Henseler, N. (2004): Ältere Arbeitnehmer und alternde Belegschaften, in: Zeitschrift für Management (ZfM), 1, 1, 70-89.

Björkman, I./Fey, C.F./Park, H.J. (2007): Institutional theory and MNC subsidiary HRM practices: Evidence from a three-Country study, in: Journal of International Business Studies, 38, 3, 430-446.

Börsch-Supan, A. (2004): Global aging: Issues, answers, more questions, mea discussion Paper No. 55-2004, July 2004.

Börsch-Supan, A./Düzgün, I./Weiss, M. (2005): Altern und Produktivität : Zum Stand der Forschung, mea Discussion Paper No. 73-2005, May 2005.

Bosch, G./Schief, S. (2005): Die Beschäftigung Älterer in Europa zwischen Vorruhestand und „Work-Line“, in: Arbeit, 14, 4, 275-290.

Bresser, R./Millonig, K. (2003): Institutional capital: Competitive advantage in light of the new institutionalism in organization theory, in: Schmalenbach Business Review (sbr), $55,3,220-241$.

Bruch, H./Kunze, F. (2007): Management einer Aging Workforce: Ansätze zu Kultur und Führung, in: Zeitschrift für Führung und Organisation (zfo), 76, 2, 72-77.

Dickmann, N. (2004): Ein demographisches Porträt der osteuropäischen Beitrittsländer, in: IW-Trends, 31, 1, 21-26.

DiMaggio, P.J./Powell, W.W. (1983): The iron cage reviseted: Institutional isomorphism and collective rationality in organisational fields, in: American Sociological Review, 48, 1, 147-160.

DiMaggio, P.J./Powell, W.W. (1991): Introduction, in: Powell, W.W./DiMaggio, P.J. (ed.): The New Institutionalism in Organizational Analysis, Chicago, IL: University of Chicago Press, 1-40.

Dupont, G. (2004): Pension reforms in acceding countries, in: Creel, J./Levasseur, S. (ed.): The New EU Enlargement, Revue de l'OFCE Special Issue, April 2004, 55-81.

Eckardstein von D. (2004): Demographische Verschiebungen und ihre Bedeutung für das Personalmanagement, in: Zeitschrift für Führung und Organisation (zfo), 73, 3, 128135.

Economic Policy Committee (2005a): The 2005 EPC Projection of Age-related Expenditure: Agreed Assumptions and Projections Methodologies, European Economy Occasional Papers No. 19, Brussels.

Economic Policy Committee (2005b): The 2005 EPC Projections of Age-related Expenditure (2004-2050) for the EU-25 Member States: Underlying Assumptions and Projections Methodologies, European Economy Special Report No. 4/2005, Brussels.

European Commission (2006): Employment in Europe 2006, Luxembourg: Office for Official Publications of the European Communities.

European Foundation for the Improvement of Living and Working Conditions (2007): Case Studies on Employment Initiatives for an Ageing Workforce, (http://www.eurofound. europa.eu/areas/populationandsociety/ageingworkforce.htm). 
Eurostat (2006): International day of older persons, News Release 129/2006, 29 September 2006.

Fultz, E./Ruck, M. (2001): Pension reform in Central and Eastern Europe: Emerging issues and patterns, in: International Labour Review, 140, 1, 19-43.

Gassmann, O./Reepmeyer, G./Walke, A. (2005): Neue Produkte für die jungen Alten, in: Harvard Business Manager, 27, 1, 62-67.

Grund, C. (2006): Altersstruktur der Belegschaft als Erfolgsfaktor für Unternehmen, in: Wirtschaftswissenschaftliches Studium (WiSt), 35, 8, 462-464.

GVG (ed.) (2002): Study on the social protection systems in the 13 applicant countries, Synthesis report, November 2002.

Harzing, A.W. (2004): Ideal jobs and international student mobility in the enlarged European Union, in: European Management Journal, 22, 6, 693-703.

Hedge, J.W./Borman, W.C./Lammlein, S.E. (2006): The aging workforce: Realities, myths, and implications for organizations, Washington: American Psychology Association.

Hertzman, C. (ed.) (1996): East-West life expectancy gap in Europe: Environmental and nonenvironmental determinants, Dordrecht/Boston/London: Kluwer.

Holzmann, R. (1999): The World Bank approach to pension reform, Social Protection Discussion Paper Series No. 9807, The World Bank, Washington.

Holzmann, R. (ed.) (2003): Pension reform in Europe: Process and progress, The World Bank, Washington.

Hoskisson, R.E.(ed.) (2000): Strategy in Emerging Economies, in: Academy of Management Journal, 43, 3, 249-267.

Karhunen, P. (2008): Towards convergence in the St. Petersburg Hotel industry through the lens of institutional theory, in: Journal for East European Management Studies (JEEMS), 13, 2, 106-128.

Kiriazov, D./Sullivan, S.E./Tu, H.S. (2000): Business success in Eastern Europe: Understanding and customizing HRM, in: Business Horizons, 43, 1, 39-43.

Kostova, T./Roth, K. (2002): Adoption of an organizational practice by the subsidiaries of the MNC: Institutional and relational effects, in: Academy of Management Journal, 45, 1, 215-233.

Krieb, C./Reidl, A. (1999): Senioren-Marketing: So erreichen Sie die Zielgruppe der Zukunft, Wien: Ueberreuter.

Lawrence, T.B. (1999): Institutional strategy, in: Journal of Management, 25, 2, 161-187.

Lührmann, M. (2005): Population aging and the demand for goods and services, mea Discussion Paper No. 95-2005, November 2005.

Meyer, K.E./Nguyen, H.V. (2005): Foreign investment strategies and sub-national institutions in emerging markets: Evidence from Vietnam, in: Journal of Management Studies, 42, 1, 63-93.

Meyer, K.E./Peng, M.W. (2005): Probing theoretically into Central and Eastern Europe: Transactions, resources and institutions, in: Journal of International Business Studies, $36,6,600-621$. 
Meyer, J.W./Rowan, B. (1977): Istitutionalized organisations: Formal structures as myth and ceremony, in: American Journal of Sociology, 83, 2, 340-363.

Meyer-Hentschel, G. (2005): Megatrend: Seniorengesellschaft, in: Pharma-Marketing Journal, $1,22-25$.

Moschis, G.P. (2003): Marketing to older adults: an updated overview of present knowledge and practice, in: Journal of Consumer Marketing, 20, 6, 516-525.

Mühlbradt, T/Grumbach, J. (2005): Arbeit und Innovation im demografischen Wandel, in: Arbeit, 14, 4, 359-363.

Müller, K. (2003): Die Rentenreformen in den mittel- und osteuropäischen EUBeitrittsländern, in: DIW Vierteljahreshefte zur Wirtschaftsforschung, 72, 4, 551-564.

Müller, K. (2005): Rentenreformen nach dem Weltbank-Modell: Erfahrungen in Mittel- und Osteuropa, in: Betriebliche Altersversorgung, 60, 1, 5-8.

Naegele, G./Wagner, A. (2006): A guide to good practice in age management, European Foundation for the Improvement of Living and Working Conditions, Dublin.

Newman, K.L. (2000): Organizational transformation during institutional upheaval, in: Academy of Management Review, 25, 3, 602-619.

Nyce, S.A./Schieber, S.J. (2005): The economic implications of aging societies: The costs of living happily ever after, New York: Cambridge University Press.

OECD (ed.) (2003): Reforming public pensions, sharing the experiences of transition and OECD Countries, Paris.

Oliver, C. (1997): Sustainable competitive advantage: Combining institutional and resourcebased views, in: Strategic Management Journal, 18, 9, 697-713.

Perlitz, M. (1989): The marketing implications of the ageing European population, in: European Business Journal, 1, 1, 26-32.

Perlitz, M. (1993): Why most strategies fail today: The need for strategy innovations, in: European Management Journal, 11, 1, 114-121.

Philipov, D. (2001): Low fertility in Central and Eastern Europe: Culture or economy? Paper presented at the IUSSP Seminar on "International Perspectives on Low Fertility: trends, theories and policies", Tokyo, March 21-23, 2001.

Philipov, D./Dorbritz, J. (2003): Demographic consequences of economic transition in countries of Central and Eastern Europe, Population studies No. 39, Directorate General III - Social Cohesion, Strasbourg: Council of Europe Publishing.

Pohl, C. (2004): Demographischer Wandel in Mittel- und Osteuropa, in: ifo Dresden berichtet, $11,5,29-36$.

Polish Information and Foreign Investment Agency (2006): The consumer market in Poland, Warsaw.

Pooler, J.A. (2003): Demographic targeting - the essential role of population groups in retail marketing, reprint, aldershot: Ashgate.

Rutkowski, J. (2006a): Inward FDI, skilled labour, and product differentiation in the CEEC, in: Journal for East European Management Studies (JEEMS), 12, 2, 91-112. 
Rutkowski, J. (2006b): Labor market developments during economic transition, World Bank Policy Research Working Paper No. 3894, April 2006.

Schaich, E. (1998): Der demographische Umbruch in Mittel- und Osteuropa: Gemeinsamkeiten und Unterschiede der Entwicklungen in den einzelnen Ländern, in: Fleischhacker, J./Münz, R. (eds.): Gesellschaft und Bevölkerung in Mittel- und Osteuropa im Umbruch, 31. Arbeitstagung der Deutschen Gesellschaft für Bevölkerungswissenschaft (DGBw), 24. und 25. April 1997 in Berlin, Tagungsband, Berlin, 7-21.

Scott, W.R. (2001): Institutions and organizations, 2nd ed., Thousand Oaks, CA: Sage.

Settergren, O. (2001): The automatic balance mechanism of the Swedish pension system - a non-technical introduction, The National Social Insurance Board Working Papers in Social Insurance No. 2001:2, August 2001.

Tolbert, P.S./Zucker, L.G.: The institutionalization of institutional theory, in: Clegg, S.R./Hardy, C./Nord, W. R. (eds.): Handbook of Organizational Studies, London: Sage, 175-190.

UNCTAD (ed.) (2005): World Investment Report 2005: Transnational Corporations and the Internationalization of R\&D, New York and Geneva.

UNECE (2000): Fertility decline in the transition economies, 1989-1998: Economic and social factors revisited, in: UNECE (ed.): Economic Survey of Europe, 1, 189-207.

United Nations (ed.) (2002): International migration from countries with economies in transition: 1980-1999, population division, Department of Economic and Social Affairs, United Nations Secretariat, New York.

United Nations (ed.) (2007): World population prospects: The 2006 revision, highlights, Department of Economic and Social Affairs, Population Division, United Nations, New York.

Wienert, H. (2007): Können alternde Gesellschaften dem Innovationsdruck standhalten?, in: Wirtschaftsdienst, 87, 6, 386-390.

Williamson, J. (2004): Assessing the Notional Defined Contribution Model, Center for Retirement Research at Boston College Issues in Brief No. 24, October 2004.

World Bank (ed.) (1994): Averting the old age crisis, policies to protect the old and promote growth, Washington DC: Oxford University Press.

Zdrowomyslaw, N.(ed.) (2005): Personalpolitik in Zeiten demografischen Wandels, in: Der Betriebswirt, 58, 2, 8-12.

Zwierzyk, J. (2006): The level and structure of consumption expenditure in Polish households, in: Electronic Journal of Polish Agricultural Universities, Economics, 9, 3. 